\title{
A Path Analysis on Writing Anxiety, Writing Attitude, Language Awareness, and Writing Achievement of University Students
}

\author{
${ }^{1}$ Dhena Usthiana Haryanti \\ Master of English Language Education Department, IAIN Kediri, Indonesia \\ ${ }^{2}$ Fathor Rasyid \\ Department of English Language Education, IAIN Kediri, Indonesia \\ ${ }^{3}$ Sri Wahyuni \\ Department of English Language Education, IAIN Kediri, Indonesia \\ Corresponding Author: haryantidhena@gmail.com
}

\begin{abstract}
During the teaching and learning process in writing context, EFL learners have their own intrinsic problems. They tend to experience some psychological tensions such as writing anxiety, writing attitude and language awareness. In line, some academical issues they need to handle in writing context are text organization, grammar, spelling, punctuation and ideas development. The aim was to find out the direct and indirect contribution among the variables. Thus, writing anxiety and writing attitude were the exogenous variable, then language awareness as mediated variable, while the writing achievement as the endogenous variable. This study applied the combination of multiple regression and mediated model as a part of Path Analysis. There were four instruments used, namely SLWAI, ATWQ, LALQ, and TOEFL Independent Writing Test. These instruments were fulfilled by 100 participants of fourth semester English Department students. The data was collected online through Google Form, Google Meet and personal chat on WhatsApp. The result shows that there was low significant direct contribution of writing anxiety toward writing achievement. Meanwhile, there was no significant direct contribution of writing attitude toward writing achievement. In addition, there was significant direct contribution of language awareness toward writing achievement. Besides, the result of indirect contribution revealed, there was no indirect contribution of writing anxiety through writing attitude toward writing achievement. Then, the indirect contribution of writing attitude through language awareness toward writing achievement was found out significant. Lastly, it was revealed that there was no indirect contribution of writing anxiety through language awareness toward writing achievement.
\end{abstract}

Keywords: language awareness, writing achievement, writing anxiety, writing attitude

\section{ABSTRAK}

Dalam konteks pembelajara menulis, pembelajar EFL biasanya memiliki masalah intrinsik pada diri mereka sendiri. Mereka cenderung mengalami beberapa tekanan psikologis seperti writing anxiety dan writing attitude. Sejalan dengan itu, beberapa masalah akademis yang perlu mereka tangani dalam konteks menulis adalah organisasi teks, tata bahasa, ejaan, tanda baca dan pengembangan ide. Tujuan dari penelitian ini adalah untuk mengetahui kontribusi langsung dan tidak langsung antar variabel. Dengan demikian, writing anxiety dan writing attitude. merupakan variabel eksogen, kemudian kesadaran bahasa sebagai variabel mediasi, sedangkan prestasi 
Dhena Usthiana Haryanti

Fathor Rasyid

Sri Wahyuni
A Path Analysis on Writing Anxiety, Writing Attitude, Language Awareness, and Writing Achievement of University Students

menulis sebagai variabel endogen. Penelitian ini menerapkan kombinasi regresi berganda dan model mediasi sebagai bagian dari Analisis Jalur. Ada empat instrumen yang digunakan, yaitu SLWAI, ATWQ, LALQ, dan TOEFL Independent Writing Test. Instrumen-instrumen tersebut diberikan kepada 100 peserta mahasiswa Jurusan Bahasa Inggris semester IV. Pengumpulan data dilakukan secara online melalui Google Form, Google Meet dan personal chat di WhatsApp. Hasil penelitian menunjukkan bahwa ada kontribusi langsung yang rendah dan signifikan dari writing anxiety terhadap kemampuan menulis. Sementara itu, tidak ada kontribusi langsung yang signifikan dari writing attitude terhadap prestasi menulis. Selain itu, ada kontribusi langsung yang signifikan dari kesadaran hasa terhadap prestasi menulis. Selain itu, hasil kontribusi tidak langsung mengungkapkan, tidak ada kontribusi tidak langsung writing anxiety melalui writing attitude terhadap prestasi menulis. Kemudian, kontribusi tidak langsung writing attitude melalui pemahaman bahasa terhadap prestasi menulis ditemukan signifikan. Terakhir, terungkap bahwa tidak ada kontribusi tidak langsung dari writing attitude melalui pemahaman bahasa terhadap prestasi menulis.

Kata Kunci: pemahaman bahasa, prestasi menulis, writing anxiety, writing attitude

\begin{tabular}{|l|l|l|}
\hline Received: January 10, 2022 & Accepted: February 19, 2022 & Published: February 23, 2022
\end{tabular} How to cite:

Haryanti. D.U., Rasyid, F., \& Wahyuni, S. (2022). A Path Analysis on Writing Anxiety, Writing Attitude, Language Awareness, and Writing Achievement of University Students. English Learning Innovation, 3(1), 85-99. https://doi.org/10.22219/englie.v3i1.19657

\section{INTRODUCTION}

Writers brings their own variety on developing and creating their writing products. They always been keeping up with their educational background, cognitive ability, interests, beliefs, ages, even anxiety (Ong, 2015). Learners on developing their ability to write are not barely come with empty head. The learners bring their own educational backgrund, learning experience even their psychological condition. In this case, it is the teachers or lecturers' duty to identify the differences and according them to develop their ability, especially in writing (Kheirabadi, 2018). Thus, every writers has their own preferences on producing writing products.

Despite that preferences, writers also has obligation to concern on writing aspects which being a basic rules to arrange a meaningfull and complex writing products, especially for academical purposes. These aspects are content, organization, grammar, vocabulary, and mechanics (Brown, 2006). Due to the fact that writing in academic context requires high mental processes, it will cause some anxieties among the writers. It is undeniable that developing writing ability in academic purposes is one of tough ability to improve (Kusumaningputri et al, 2018). In this case, concern on learner's psychological condition during their teaching and learning process is important. In addition, learners that have a positive psyhological tension will bring them into better achievement, vice versa. 
Dhena Usthiana Haryanti

Fathor Rasyid

Sri Wahyuni
A Path Analysis on Writing Anxiety, Writing Attitude, Language

Awareness, and Writing Achievement of University Students

Anxiety is natural feeling that may happen in different situations, especially in academic scope (Miri \& Joia, 2018). Thus, language anxiety is a major and common phenomenon faced by EFL learners. Daly in Kırmızı and Kırmızı (2015) believed that writing anxiety is a situation which learners avoid the task of writing less confidence when the lecturer check their writing task, fear of negativity and evaluation, the development of complex ideas and current issues, and time limitation (Wahyuni \& Umam, 2017; Kırmızı\&Kırmız1, 2015). Basically, writing anxiety categorized into four, these are somatic anxiety, cognitive anxiety and avoidance behaviour (Cheng, 2004). The EFL learners' tension on writing anxiety will affected their attitude toward writing. the lower writing that learners fell, the more outstanding their writing achievement.

Writing attitude is one of grammatical issues to discuss and it has complexity affecting the learners' writing achievement. Attitude toward language learning is a conviction, feeling, and response from language learning to any item, material, or teaching and learning situation (Riyanto et al, 2015). In general, attitude toward language were devided into two aspects, these are positive and negative attitude. Positive attitude which contribute the learners' succes foreign language learning. Meanwhile, negative attitude the failed the learners' foreign language learning (Coşkun \& Taşgın, 2018). Language attitudes can have a great influence in areas such as education (Holmes, 2013). Thus, it is important to determine, including the learners' overall motivation which affecting their motivation toward writing (Thornbury, 2016). Unfortunately, EFL learners were found did not consistently improve their writing ability. According to the experience of Pajares and Variante showed if the learners are unwilling to express themselves, lack of confidence on their ability to write, feels apprehensive about writing, then the learners are unlikely to be proficient at writing composition (Erkan \& Saban, 2011).

EFLs' anxiety and attitude on writing are crucial to consider as a psychological tension which contribute on their writing achievement. On the other side those two aspects were able to be the reflection of their awareness toward language. Learning foreign language for academic purposes is not only focus on the development of EFLs ability, but they have certain goals to achieve. Language awareness can be defined as an explicit knowledge about language, conscious perception and sensitivity in language learning, language teaching and language use (Svedberg, 2007). Thus, a language awareness approach contribute to the development of learners' criticial thinking skills, support the learners in gaining insight into their language learning process and also help them connect the various aspects of language learning (Broek et 
Dhena Usthiana Haryanti

Fathor Rasyid

Sri Wahyuni
A Path Analysis on Writing Anxiety, Writing Attitude, Language

Awareness, and Writing Achievement of University Students

al, 2019). In line, the development of language awareness also takes place in social interactions which requires the language users' knowledge (Astuti, 2020).

The objectives of the study were figured out the directs and indirects contributions among the variables used. Then, the purposes of the study finally stated to figure out the direct contributions of writing anxiety, writing attitude, and language awareness toward writing achievement. In addition, the indirect contributions of writing anxiety through writing attitude, writing attitude through language awareness, and writing anxiety through language awareness toward writing achievement of English Department students at IAIN Kediri.

\section{METHOD}

There were four variables developed in this study and these are writing anxiety, writing attitude, language awareness, and writing achievement. These variables were grouping into three sections. The exogenous variable (independent variable) were writing anxiety and writing attitude, the mediated variable was language awareness while the endogenous variable (dependent variable) was writing achievement. Thus, the combination of multiple regression and mediated model were required as the research design (Sarwono, 2012). This research design is part of Path Analysis and it is the development part of regression analysis (Sugiyono, 2016).

The participants of this study were fourth semester of English Department Students of IAIN Kediri. Brown stated that the university students were already categoried as adult learners which already experienced some psychological tensions during their teaching and learning process on developing language ability especially on writing development (Brown, 2000). For the minimum requirement of Path Analysis, then 100 participants were contributed into this study (Sarwono, 2011).

There were four different istruments used. SLWAI (Second Language Writing Anxiety Inventory) Questionnare was used in order to gather the data of writing anxiety, adapted from Cheng (2004) and consist of 20 items. Then, ATWQ (Attitude Toward Writing Questionnaire) consist of 20 items, adapted from Kadhim (2019) and applied to collect the participants' writing attitude. Next, LALQ (Learners Awareness Levels Questionnaire) was used to gather the learners' language awareness, consist of 18 items and adapted from Choy (2015). Meanwhile, to gather the data from learners' writing ability, the researcher adapted the TOEFL Independent Writing Test from TOEFL Resource developed by Goodine (2021). All of the instruments used were validated by expert validator and tested by validity and reliability test using SPSS. 
Dhena Usthiana Haryanti

Fathor Rasyid

Sri Wahyuni
A Path Analysis on Writing Anxiety, Writing Attitude, Language

Awareness, and Writing Achievement of University Students

\section{FINDINGS AND DISCUSSION}

In order to fulfill the Path Analysis requirements, Normality Test of all variables, Test of Linearity and Linier Regression were conducted. In line, the calculation results of Prerequisite Test for Path Analysis can be seen in the following tables.

Table 1. The Normality Test of Four Variables

\begin{tabular}{|c|c|c|c|c|c|}
\hline \multicolumn{6}{|c|}{ One-Sample Kolmogorov-Smirnov Test } \\
\hline & & $\begin{array}{l}\text { Writing } \\
\text { Anxiety }\end{array}$ & $\begin{array}{l}\text { Writing } \\
\text { Attitude }\end{array}$ & $\begin{array}{c}\text { Language } \\
\text { Awareness }\end{array}$ & $\begin{array}{c}\text { Writing } \\
\text { Achievement }\end{array}$ \\
\hline $\mathrm{N}$ & & 100 & 100 & 100 & 100 \\
\hline \multirow[t]{2}{*}{ Normal Parameters ${ }^{\mathrm{a}}$} & Mean & 64.81 & 63.36 & 63.32 & 59.70 \\
\hline & Std. Deviation & 8.037 & 8.130 & 10.090 & 15.809 \\
\hline \multirow[t]{3}{*}{ Most Extreme Differences } & Absolute & .129 & .176 & .101 & .120 \\
\hline & Positive & .051 & .117 & .101 & .120 \\
\hline & Negative & -.129 & -.176 & -.073 & -.083 \\
\hline Kolmogorov-Smirnov Z & & 1.294 & 1.758 & 1.014 & 1.203 \\
\hline Asymp. Sig. (2-tailed) & & .070 & .004 & .255 & .111 \\
\hline
\end{tabular}

a. Test distribution is Normal.

According to the statistical computation result above, the data were all normally distributed except for the distribution of Writing Attitude Questionnaire. The Asp. Sig. (2tailed) was .004 which lower than .05. Then, another normality test result of Writing Anxiety, Language Awareness and Writing Achievement were .070, .255, and .111 which higher than .05 .

Table 2. The Result of Linearity Test among Variables

\begin{tabular}{cc}
\hline Variables & Sig. \\
\hline Writing Anxiety and Writing Achievement & .599 \\
Writing Attitude and Writing Achievement & .658, \\
Language Awareness and Writing Achievement & .245, \\
\hline
\end{tabular}

As stated above, the linearity test results showed that the significancy of writing anxiety and writing achievement is .599 , writing attitude and writing achievement is .658 , while language awareness and writing achievement is .245. Those results are bigger than .05 , which means that writing anxiety, writing attitude and language awareness have positive linearity toward writing achievement.

\section{a. Linier Regression}

Linier Regression conducted to figure out the significance and degree of endogenous and exogenous variables of the study. The result of the statistical calculation has addressed into the following table. 
Dhena Usthiana Haryanti

Fathor Rasyid

Sri Wahyuni
A Path Analysis on Writing Anxiety, Writing Attitude, Language

Awareness, and Writing Achievement of University Students

Table 3. The Result of Linier Regression

\begin{tabular}{cccc}
\hline Variables & R & R Square & Sig. \\
\hline Writing Anxiety and Writing Achievement & $.288^{\mathrm{a}}$ & .083 & $.004^{\mathrm{a}}$ \\
$\begin{array}{c}\text { Writing Attitude and Writing Achievement } \\
\begin{array}{c}\text { Language Awareness and Writing } \\
\text { Achievement }\end{array}\end{array}$ & $.340^{\mathrm{a}}$ & .116 & $.001^{\mathrm{a}}$ \\
$\quad .510^{\mathrm{a}}$ & .260 & $.000^{\mathrm{a}}$ \\
\hline
\end{tabular}

The amount of R Square showed the result of regression model between endogenous and exogenous variables. The influence of writing anxiety toward writing achievement is 8.3\% (R Square .083) along with the Sig. .004, lower than .05 which showed positive and significant effect. In line, the amount effect of writing attitude toward writing achievement was $11.6 \%$ (R Square .116) and the Sig. was .001, which also showed the positive and significant effect. In addition, the amount effect of language awareness toward writing achievement is $26 \%$ ( $\mathrm{R}$ Square .260), followed by the Sig. .000, hence it has positive and significant effect.

The calculation results on the previous points have already fulfilled the Path Analysis requirement. Hence, the researcher could continue the Path Analysis calculation by Amos which had completely addressed in the following point along with the Model.

Figure 1. Path Analysis Model

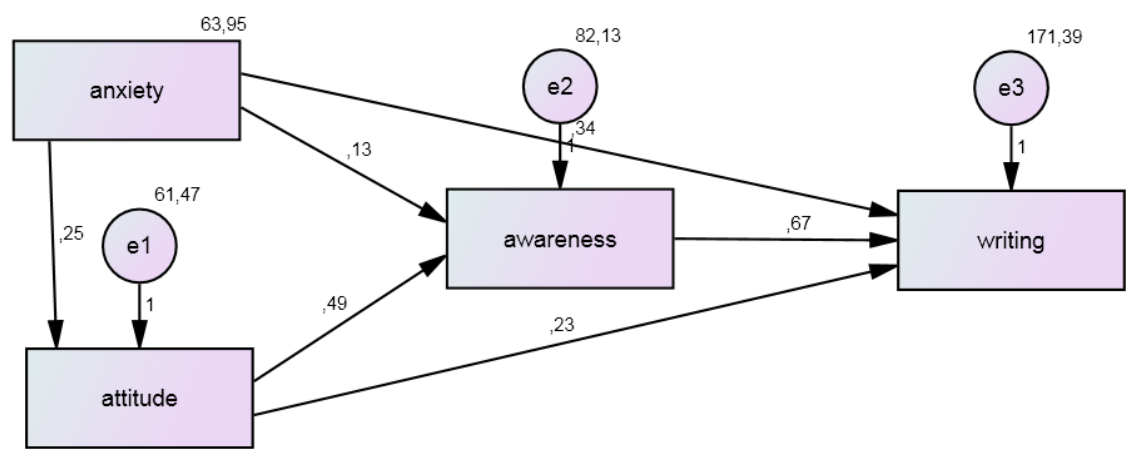

Table 4. Regression Weights for Proposed Model

\begin{tabular}{cccccccc}
\hline & & & Estimate & S.E. & C.R. & P & Label \\
\hline Attitude & $<---$ & anxiety & .249 & .099 & 2.526 & .012 & par_6 \\
Awareness & $<---$ & anxiety & .128 & .118 & 1.090 & .276 & par_2 \\
Awareness & $<---$ & attitude & .489 & .116 & 4.207 & $* * *$ & par_3 \\
Writing & $<---$ & anxiety & .342 & .171 & 2.002 & .045 & par_1 \\
Writing & $<---$ & Attitude & .232 & .182 & 1.271 & .204 & par_4 \\
Writing & $<---$ & Awareness & .666 & .145 & 4.589 & $* * *$ & par_5 \\
\hline
\end{tabular}


Dhena Usthiana Haryanti

Fathor Rasyid

Sri Wahyuni
A Path Analysis on Writing Anxiety, Writing Attitude, Language

Awareness, and Writing Achievement of University Students

\section{Finding on Directs Contribution among the Variables}

In order to achieve the purpose of the study, the direct contributions among those variables were finally came out. The direct contribution of writing anxiety into writing achievement (writing <--- anxiety), showed the estimate value was .342 and it has weak contribution. While the P.value was .045; which lower than .05. Besides, the CR (Critical Ratio) was 2.002; greater than 1.96 at $5 \%$ significant level. In conclusion, writing anxiety had direct contribution toward writing achievement. From the previous statistical data, it had proven that writing anxiety has a weak contribution toward writing achievement. However, it still has enough evidence that it had a significant contribution even though anxiety is one of a dominant tension faced by learners, especially for the EFL (Kusumaningputri, Ningsih, \& Wisasongko, 2018). But on the other side, in turn, this anxiety tension might also help the learners to achieve their learning goals in English (Hakim, 2019). It means that anxiety does not always give bad effect on the learners' learning process. In line, the EFL learners will always have anxiety tension while showing their best ability in their writing performance. Meanwhile, the participants of the study were university students whom categorized as adult learners. Then, it can be one of another reason that adult learners also understand of the importance of developing their writing ability (Broughton, 1980). This means that learners can already control and manage their writing practice. Progress should be made and it should be proven.

The second result of statistical computation for direct contribution of writing attitude toward writing achievement (writing <--- attitude) as the estimate value was .232, which means it has weak contribution. Then, the P. value was .204; greater than .05. along with the CR (Critical Ratio) was 1.271; lower than 1.96 at 5\% significant level. In this case, the result showed that writing attitude has no significant direct contribution toward writing achievement. The statistical computation result of this study had proven that writing attitude has no direct contribution toward learners' writing achievement. This result is supported by the previous study of Setyowati and Sukmawan, that most of the EFL learners tend to have a negative attitude (Setyowati \& Sukmawan, 2019). Basically, every learner has the right to choose and decide which area they want to put their desire on. This means that every individual does not merely accept the value of what they are learning.

Meanwhile, they need time to commit and point out what they are convincing toward their own beliefs or attitude (Brown, 2006). In addition, learners at the university level also need space to express their feeling, thoughts and find out their desire in English Language 
Dhena Usthiana Haryanti

Fathor Rasyid

Sri Wahyuni
A Path Analysis on Writing Anxiety, Writing Attitude, Language

Awareness, and Writing Achievement of University Students

Teaching (Kadhim, 2019). Ideally, learners should have a positive attitude as it can support their writing achievement (Setyowati \& Sukmawan, 2019). Practically, enhancing writing skills is much more in demand for EFL learners (AlMawarni, 2020). They came from different backgrounds, needs, and interests. Specifically, every learner has their own goals to achieve. Thus, it could affect their attitude toward ELT, especially on their writing achievement. In that case, it might happen because they are not confident enough to show their best performances and tend to fear being evaluated (Setyowati \& Sukmawan, 2019). Then it can be concluded that EFL learners tend to have a low attitude toward writing.

The last statistical computation showed the significant calculation result of direct contribution of language awareness toward writing achievement (writing <--- awareness), which showed that the estimate value was .666, which means it has strong contribution. The P. value was .000; which lower than .05. Besides, the CR (Critical Ratio) was 4.589; greater than 1.96 at $5 \%$ significant level. Hence, it showed that language awareness had directly contributed the writing achievement, which means language awareness affected the learners' writing achievement. The EFL learners truly need some power to keep improving and developing their writing ability to achieve better achievement. In some or specific ways, every learners always affected by how language is used (Farahian \& Raezae, 2015). Meanwhile, the learners' writing products will always permanently exist. Then, many aspects should be concern in order to produce appropriate and meaningful written products. In this case, learners' maintain the writing development ideas, but they also need to concern about their ability in the language use.

Due to the language in use, highlighting the importance of writing and raising awareness of the language used is crucial, especially for EFL learners. In addition, increasing their preception toward writing ability is needed to focus on their goals and for better achievement (Al-Mukdad, 2019). When the EFL learners are already aware of their language use, they will have positive perspective during the teaching and learning process and became curious about what they learned (van Lier, 2001). In addition, the learners had to experience self-gained realization to achieve their learning goals (Lin, 2001). Thus, learners could get some benefits from raising awareness for their learning process (Brown, 2006). This means that enhancing the learners' consciousness and sensitivity in the form and function of language is definitely beneficial for the learners' achievement (Astuti, 2020).

\section{Finding on Indirect Contribution among the Variables}

Table 5. Statistical Computation Result of Sobel Test 
Dhena Usthiana Haryanti

Fathor Rasyid

Sri Wahyuni
A Path Analysis on Writing Anxiety, Writing Attitude, Language

Awareness, and Writing Achievement of University Students

\begin{tabular}{|c|c|c|c|}
\hline Variables & Test Statistic & Std. Error & $P$ value \\
\hline $\begin{array}{c}\text { writing anxiety through writing attitude toward } \\
\text { writing achievement }\end{array}$ & 1.137 & 0.0508 & 0.25 \\
\hline $\begin{array}{l}\text { writing attitude through language awareness } \\
\text { toward writing achievement }\end{array}$ & 3.11 & 0.11 & 0.001 \\
\hline $\begin{array}{l}\text { writing anxiety through language awareness } \\
\text { toward writing achievement }\end{array}$ & 1.056 & 0.0807 & 0.3 \\
\hline
\end{tabular}

The researcher found that the indirect contribution of writing anxiety through writing attitude toward writing achievement was found out nothing. The result of Sobel Test was 1.137 which is smaller than 1.96., and along with standard of error 0.0508. In addition, the Pvalue was 0.25 , which higher than .05 . All in all, there was no significant indirect distributions of writing anxiety through writing attitude toward writing achievement. Meanwhile, MacIntyre and Gregersen stated, foreign language anxiety is negative and fearful feeling experiencing by students which affected by the individual's learning process or use of a nonnative language (Coşkun \& Taşgın, 2018). For EFL learners society, feeling anxiety is a standard psychological pressure experienced by these learners due to the learning goals and language components which they need to understand. Besides, these EFL learners also need time to elaborate on their language used with the target language they need to achieve.

However, developing writing ability is quite tricky for EFL learners since it is crucial for academic success; writing also has several essential occultations to concern. Therefore, it is undeniable that writing for almost all foreign language learners is a tough task to achieve in specific purposes (Kusumaning, 2018). Hence, not all EFL learners already have good skills on writing. As a result, the learners will lack practicing and less improving. It might cause the students to avoid writing activities. Learners with a negative attitude toward English will be experiencing higher anxiety levels. Meanwhile, learners' attitude toward foreign language learning influences the level of its success and vice versa (Coşkun \& Taşgın, 2018). Some progress might be made, but they might also do not show their best performance.

The indirect contribution of writing attitude through language awareness toward writing achievement was revealed significantly contributed. The statistical test result of Sobel was 3.11, which higher than 1.96 , along with the standard of error 0.11 , followed by the P-value was 0.001 , which lower than .05. Attitude on language learning is a tension of excitement feeling, representing the learners' psychological situation during the teaching and learning process. Ideally, the learners should have a positive attitude to make sure that their learning processes are enjoyable. When the learners are interested in learning English, especially in 
Dhena Usthiana Haryanti

Fathor Rasyid

Sri Wahyuni
A Path Analysis on Writing Anxiety, Writing Attitude, Language

Awareness, and Writing Achievement of University Students

writing, it will also lead them to have better language use understanding. Based on these definitions, language awareness is noted influencing the learners' teaching and learning process (Astuti, 2020).

In fact, producing an appropriate written text is always challenging for EFL learners. However, developing writing ability for university students is still one of an essential productive skills in order to achieve the academic purposes (Abadikah, Aliyan, \& Hassan, 2018). Based on this situation, learners' language awareness contributes on affecting the tendency of their writing achievement. In addition, the contribution comes from the learners' attitude and awareness as well as the EFL teachers, which tend to encourage the learners' writing achievement through the teaching program.

For the last, indirect contribution result of writing anxiety through language awareness toward writing achievement, the test statistic of Sobel test was 1.056, which smaller than 1.96. While the standard of error was 0.0807 , along with the P-value was found out 0.3 , which definitely higher than .05 . Hence, it can be concluded that writing anxiety has no indirect contribution toward writing achievement through language awareness. In this case, it is possible to happen that the learners tend to experience anxiety that negatively affected them. Anxiety can play a significant role in the learners' success in learning language, whether positive or negative. The university students might experience some pressure during their teaching and learning process on writing, such as being nervous, stressed, and anxious, which typical EFL learners face (Miri \& Joia, 2018). At the same time, the learners worried a lot about their exam results, lack of vocabularies, less writing practice, confusion with the requirement of the genre in writing, and they were slow in writing English (Liu \& NI, 2015).

Inline, another related study showed several most dominant factors which affected EFL learners' writing anxiety. Those were classroom assignments, time limitation while making the assignment, the writing topic chosen by the lecturer, individual assignment, the lecturer, and the arrangement of the ideas for content development on writing (Jawas, 2019). If they tend to have anxiety about writing, the tendency to avoid writing activities is getting bigger. As a result, it will lead them to produce inferior writing quality products. The effect of anxiety is on the learners' writing products, but it also affects their awareness of language use. Meanwhile, students' awareness of English strongly affected by their management of foreign language anxiety (Trang, 2012).

From those statistical computations, it finally revealed the direct and indirect contribution of the variables used in this quantitative study. Writing anxiety has low correlation but directly 
Dhena Usthiana Haryanti

Fathor Rasyid

Sri Wahyuni
A Path Analysis on Writing Anxiety, Writing Attitude, Language

Awareness, and Writing Achievement of University Students

contribute the writing achievement. In contrast, writing anxiety has no indirect contribution toward the learners' writing achievement through writing attitude. In this case, the main concern is that as long as the students keep practicing their writing their Anxiety will get low (Morali \& Boran, 2021). During the teaching and learning process, students might experience some anxiety but it is actually normal condition, especially for EFL learners. Since then, there are several complicated aspects that need to concern in writing, students will face higher tension on experiencing anxiety.

On the other side, writing attitude has no direct contribution, but indirectly contributed the learners' writing achievement through language awareness. If the negative attitude has more tendency on learners' writing ability, it will never build up their writing achievement. In contrast, if the positive attitude plays its rule during the teaching and learning process, it will make the students enjoy their education and achieve higher achievement (Udu, 2021). Thus, language awareness is needed to help the EFL learners understand their needs during ELT process. It plays role as a bridge, between the learners' attitude and their achievement toward writing. In line, language awareness highly correlated with writing abilities, which focus on its function and development in education areas (Riehl, 2021). Thus, learners need figuring out their need in order to understand the language use correctly.

Language awareness showed that it has significant direct contribution toward writing achievement. In writing context, language awareness helps the learners to understand the function of language use, which actually crucial to concern (Farahian \& Raezae, 2015). In addition, increasing their ability is not only focus from its ability aspects, but also another psychological aspect which effects the learners' psychology condition during the teaching and learning process. In this case, the learners need to encourage their own language awareness (Riehl, 2021) since the university learners are categorized as adult learners, they need to understand these in order to keep productive on writing.

\section{CONCLUSION}

Being foreign language learners are quite challenging, since there are a lot of obstacles that learners have to face in order to master their language ability, especially in writing, thus developing the learners' writing ability is not that easy. Since it has some specific aspects to concern along with some psychological problems faced by EFL learners during their English Language Teaching. For university learners, they need to discover their own need in order to achieve better achievement. It means, the learners themselves need to aware on the language use. Meanwhile, experiencing some anxiety is common problems faced by university learners. 
Dhena Usthiana Haryanti

Fathor Rasyid

Sri Wahyuni
A Path Analysis on Writing Anxiety, Writing Attitude, Language

Awareness, and Writing Achievement of University Students

But in this case, they need to understand its own risk since they already concern to focus on foreign language studies. Thus, teachers' rule during the teaching and learning process will be helpful for the learners when they already find some obstacles.

In line, their attitude toward writing also effects their writing performance. This study found out that writing attitude will indirectly contribute their writing achievement as long as the students also keeping up with their language use. That is why, language awareness plays crucial role in order to shape the learners' awareness on their own language ability. All in all, developing the learners' writing ability does not only focus on the goals they want to achieve, but also considering on the learner psychological tension which definitely effect their learning performance and achievement. Another main concern on developing better achievement in writing is that every learner has to realize what should they concern in order to maximize their writing performance. In this case, keep improving and keep practicing their writing will always bring them into better achievement, especially in writing.

\section{REFERENCES}

Abadikah, S., Aliyan, Z., \& Hassan, S. (2018). EFL Students' Attitudes toward Self-Regulated Learning Strategies in Academic Writing. Issues in Educational Research, 1-17.

AlMawarni, M. (2020). Academic Writing Challenges and Potential Solutions. Arab World English Journal (AWEJ), 14-121.

Al-Mukdad, S. (2019). Investigating English Academic Writing Problems Encounters by Arab International University Students. Theory and Practice in Langugae Studies, 301-312.

Astuti, C. W. (2020). Language Awareness: Language Use and Reasons for Code-Switching. A Journal on Language and Language Teaching, XXIII(1), 116-130.

Broek, E. W., Oolbekkink-Marchand, H. W., Kemenade, A. M., Meijer, P. C., \& Unsworth, S. (2019). Stimulating Language Awareness in the Foreign Language Classroom: Exploring EFL Teaching Practices. The Language Learning Journal, 1-15.

Broughton, G. (1980). Teaching English as a Foreign Language. New York: Routledge Edition Book. 
Brown, H. D. (2000). Teaching by Principles An Interactive Approach to Language Pedagogy (2nd ed.). London: Pearson.

Brown, H. D. (2006). Principle of Language Teaching and Learning (5th ed.). London: Pearson.

Cheng, Y. (2004). Journal of Second Language Writing. Research Gate, XIII, 313-335.

Cheng, Y. (2004). Journal of Second Language Writing. Research Gate, 313-335.

Choy, C. (2015). Learner Awareness Levels Questionnaire: Development and Preliminary Validation of the English and Malay Versions to Measure How and Why Students Learn. Research Gate , 425-429.

Coşkun, G., \& Taşgın, A. (2018). An Investigation of Anxiety and Attitudes of University Students towards English Courses. Journal of Language and Linguistic Studies, XIV(2), 135-153.

Daly, J. (1978). Writing apprehension and writing competency. Journal of Educational Research, 10-12.

Erkan, D. Y., \& Saban, A. İ. (2011). Writing Performance Relative to Writing Apprehension, Self-Efficacy in Writing, and Attitudes towards Writing: cA Correlational Study in Turkish Tertiary-Level EFL. Asian EFL Journal, XIII(1), 164-192.

Farahian, M., \& Raezae, M. (2015). Language Awareness in EFL Context: An Overview. International Journal of Language, Literature and Culture, , 19-23.

Goodine, M. (2021, July 18). TOEFL Independent Writing Master Guide.

Hakim, B. M. (2019). A Study of Language Anxiety among English Language Learners in Saudia Arabia. AWEJ, 64-72.

Holmes, J. (2013). An Introduction to Sociolinguistics (4th ed.). New York: Routledge.

Jawas, U. (2019). Writing Anxiety among Indonesian EFL Students: Factors and Strategies" . International Journal of Instruction, 733-746. 
Dhena Usthiana Haryanti

Fathor Rasyid

Sri Wahyuni
A Path Analysis on Writing Anxiety, Writing Attitude, Language Awareness, and Writing Achievement of University Students

Kadhim, B. H. (2019). The Effect of PAPSA Model on Iraqi EFL University Students ${ }^{e e}$ Writing Performance and Attitude. International Journal of English Language, Literature in Humanities, 582-610.

Kheirabadi, S. (2018). The Role of Psychology in Teaching English Language as Foreign Language. Humanities, Arts and Literature, XI(5), 167-172.

Kırmızı, Ö., \& Kırmızı, D. (2015). An Investigation of L2 Learners' Writing Self-Efficacy, Writing Anxiety and Its Causes at Higher Education in Turkey. International Journal of Higher Education, IV(2), 57-66.

Kusumaningputri, R., Ningsih, T. A., \& Wisasongko. (2018). Secong Language Writing Anxiety of Indonesian EFL Students. Lingua Cultura, XII(4), 357-362.

Lin, Y. (2001). A Language Awareness Approach to English Language Teaching in Joint Programs in China. Proceedings of The 16th Conference of Pan-Pcific Association of Applied Linguistics, 123-128.

Liu, M., \& NI, H. (2015). Chinese University EFL Learners' Foreign Language Writing Anxiety; Pattern, EFfect and Causes. English Language Teaching, 46-58.

Miri, M. A., \& Joia, J. (2018). Writing Anxiety in an Afghan EFL Setting: Voices From Five Afghan Students. Journal of Foreign Language Teaching \& Learning , 14-29.

Morali, G., \& Boran, M. (2021). Exploring the Relationship between Writing Anxiety and Writing Self-Efficacy of International Students Learning Turkish as a Aecond Language . Cypriot Journal of Educational Sciences , 2025-2036.

Ong, J. (2015). Do Individual Differences Matter to Learners' Writing Ability? The Asian Journal of Applied Linguistics, II(2), 129 - 139.

Riehl, C. M. (2021). The Interplay of Language Awareness and Bilingual Writing Abilities in Heritage Language Speakers. Languages, 1-23.

Riyanto, S., \& all., e. (2015). The Role of Attitude to Language Learning in Readng Comprehension. Media Neliti Publication, 3-12.

Sarwono, J. (2011). Mengenal Path Analysis: Sejarah, Pengertian Dan Aplikasi. Jurnal Ilmiah Manajemen Bisnis Ukrida, XI(2), 285-296. 
Sarwono, J. (2012). Path Analysis dengan SPSS: Teori, Aplikasi, Prosedur Analisis untuk Riset Skripsi, Tesis dan Disertasi. Jakarta: Elex Media Komptindo.

Setyowati, L., \& Sukmawan, S. (2019). EFL Indoenesian Students' Attitude toward Writing in English. Arab WOrld English Journal (AWEJ), 365-378.

Sugiyono. (2016). Statistika Untuk Penelitian. Bandung: Penerbit Alfabeta .

Svedberg, A. M. (2007). Language Awareness and Language Learning. Language Teaching, IV(4), 287-308.

Thornbury, S. (2016). An A-Z of ELT . London: Macmillan.

Trang, T. T. (2012). A Review of Horwitz, Horwitz and Cope's Theory of Foreign Language Anxiety and the Challenge of the Theory. Canadian Center of Science and Education, $69-75$.

Udu, T. T. (2021). Teachers' and Students' Attitudes towards Reading and Writing: Do They Correlate to Students' Achievement in English? Studies in English Language and Education, 143-156.

van Lier, L. (2001). Language Awareness: The Cambridge Guide to Teaching English to Speakers of Other Language. Cambridge: CUP.

Wahyuni, S., \& Umam, K. (2017). An Analysis on Writing Anxiety of Indonesian EFL College Learners. JEELS, IV(1), 105-128. 